\title{
ENSINO DE FILOSOFIA FRENTE AOS DESAFIOS DA ESCOLA SEM PARTIDO
}

\author{
Webert Ribeiro de Oliveira (PPGEDUC/UNEB)* \\ https://orcid.org/0000-0001-5884-559X \\ Luciano Costa Santos (PPGEDUC/UNEB)**
}

\section{RESUMO}

O objetivo deste artigo é repensar o ensino de filosofia à luz de uma reflexão crítica sobre o movimento Escola Sem Partido. Com base no pensamento de Paulo Freire, colocamo-nos diante de um horizonte de alteridade ética, de inspiração utópica, que toma o educando como principal razão de ser da aprendizagem. As narrativas do movimento Escola Sem Partido, por sua vez, quando recorrem à postura acrítica de neutralidade axiológica no ambiente escolar, agem sob o pressuposto de que os valores da família tradicional se encontram ameaçados pela ideologia de gênero. A censura à diversidade resulta no delineamento de uma única concepção política. Assim, as narrativas jurídicas e persecutórias do movimento Escola Sem Partido acabam produzindo um reforço da educação bancária. Não obstante, o bom ensino de filosofia requer a criação do saber em uma mediação cognitiva, aberta e dinâmica, entre sujeitos cognoscentes e fenômenos cognoscíveis. Na busca da dimensão ontológica do humano, à luz da pedagogia de Freire, encontramos no método dos círculos de cultura um desejo de democratização da palavra, constituindo como fonte de sentido o compartilhamento do poder através da participação consciente.

Palavras-chave: Ensino de filosofia. Escola Sem Partido. Ética da alteridade.

\section{ABSTRACT}

\section{TEACHING PHILOSOPHY IN FRONT OF THE CHALLENGES OF SCHOOL WITHOUT A PARTY}

The aim of this article is to rethink the teaching of philosophy in the light of a critical reflection on the School Without Party movement. Based on the thought of Paulo Freire, we are faced with a horizon of ethical otherness, of utopian inspiration, which takes the student as the main raison d'être of learning. The narratives of the Escola Sem Partido movement, in turn, when they resort to the uncritical stance of axiological neutrality in the school environment, act

\footnotetext{
Mestre em Educação e Contemporaneidade pela Universidade do Estado da Bahia (UNEB). Membro do Grupo de Pesquisa sobre Pensamento e Contemporaneidade (PPGEDUC/UNEB). E-mail: webertfilosofia@yahoo.com.br

** Pós-Doutor em Filosofia Moral e Política pela Universidad Autónoma Metropolitana (UAM) do México. Doutor em Filosofia pela Pontifícia Universidade Católica do Rio Grande do Sul (PUC/RS). Credenciado como professor permanente no Programa de Pós-Graduação em Educação e Contemporaneidade (PPGEDUC/UNEB). Líder do Grupo de Pesquisa sobre Pensamento e Contemporaneidade (PPGEDUC/UNEB). E-mail: lucostasantos1@gmail.com
} 
under the assumption that the values of the traditional family are threatened by gender ideology. The censorship of diversity results in the outline of a single political conception. Thus, the legal and persecutory narratives of the Escola Sem Partido movement end up reinforcing banking education. Nevertheless, good teaching of philosophy requires the creation of knowledge in a cognitive, open and dynamic mediation, between knowing subjects and knowing phenomena. In the search for the ontological dimension of the human, in the light of Freire's pedagogy, we find in the method of cultural circles a desire to democratize the word, constituting the sharing of power through conscious participation as a source of meaning..

Keywords: Philosophy teaching. School Without Party. Ethics of alterity.

\section{RESUMEN}

\section{ENSEÑANZA DE FILOSOFÍA FRENTE A LOS DESAFÍOS DE LA ESCUELA SIN UNA FIESTA}

El objetivo de este artículo es repensar la enseñanza de la filosofía a la luz de una reflexión crítica sobre el movimiento Escuela Sin Partido. Basado en el pensamiento de Paulo Freire, nos enfrentamos a un horizonte de alteridad ética, de inspiración utópica, que toma al estudiante como la principal razón de ser del aprendizaje. Las narrativas del movimiento Escuela Sin Partido, a su vez, cuando recurren a la postura acrítica de neutralidad axiológica en el entorno escolar, actúan bajo el supuesto de que los valores de la familia tradicional están amenazados por la ideología de género. La censura de la diversidade da como resultado la delineación de una concepción política única. Así, las narrativas legales y persecutorias del movimiento Escuela Sin Partido terminan reforzando la educación bancaria. Sin embargo, una buena enseñanza de la filosofía requiere la creación de conocimiento en una mediación cognitiva, abierta y dinámica, entre sujetos y fenómenos de conocimiento. En la búsqueda de la dimensión ontológica del ser humano, a la luz de la pedagogía de Freire, encontramos en el método de los círculos culturales un deseo de democratizar la palabra, constituyendo el intercambio de poder a través de la participación consciente como fuente de significado.

Palabras clave: Enseñanza de la filosofía. Escuela sin fiesta. Ética de la alteridad.

\section{A ética do bem pensar no contexto da Escola Sem Partido}

Quando se trata da tarefa libertadora de elevação da consciência ingênua à reflexiva no pensamento de Paulo Freire, não podemos anular a importância da ética da alteridade, cuja concepção de responsabilidade norteia o sentido do encontro, a partir da estética da sensibilidade como disponibilidade a ser afetada pelos outros. Por isso, ensinar exige, para
Freire (1996), segundo a obra Pedagogia da autonomia, um exame crítico semelhante a um parto doloroso e permanente em relação aos desvios e situações limites impostos à prática docente, que aparecem como desafio ao longo da caminhada.

Dessa maneira, apenas através do escrutínio crítico das escolhas que fazemos frente às 
responsabilidades assumidas, podemos tornar nossas ações passíveis de fecunda reflexão ética. Neste sentido, a prática educativa não pode ser reduzida à experiência técnica, muito comum nas sociedades pós-modernas, que funcionam, segundo Lyotard (2011), através do princípio do desempenho, subordinando as instituições à legitimidade do saber a partir do poder constituído. Assim, na era da globalização, conforme o Dicionário Paulo Freire (STRECK; REDIN; ZITKOSKI, 2008), a verdadeira humanização só é possível por via da reflexão ética como posição radical contra a ditadura do mercado, representada pelo poder econômico das elites, que reduzem a educação a uma mera relação de consumo, sob a perspectiva de uma globalização neoliberal.

Por isso, afirma Freire (2016, p. 25, grifo do autor) na obra Pedagogia da tolerância, publicação organizada por Ana Maria Araújo Freire:

Da tolerância, da educação, da democracia. Mas não da tolerância como pura condescendência ou indulgência que A tem ou experimenta em relação a B. Neste sentido, a tolerância implica um certo favor que o tolerante faz em relação ao tolerado. 0 tolerante, em última análise, é uma pessoa disposta, bondosa ou benevolente, a perdoar a 'inferioridade' do outro.

A tolerância, quando visualizada sob a perspectiva de uma racionalidade abstrata e alienante, produz uma falsa consciência de que ser tolerante é um certo favor que a classe dominante detentora do poder econômico realiza, a partir da narrativa ideológica da sua superioridade racial, de classe e de gênero, introjetando nos oprimidos, através da política de parcas concessões, uma concepção abstrata de sujeitos tolerantes. Não obstante, a educação democrática se apresenta na história como um ato político de diferentes significações, cujo sentido de tolerância é criticamente concebido em sua dimensão ética.

Na medida em que o educador, para Freire (2016), é um ser político e militante, sua opção surge a partir do questionamento que faz em torno do Outro que o interpela. 0 educador se encontra em estado de poiésis, ${ }^{1}$ mobilizado na produção de uma obra conjunta, em que o educando constitui a principal razão de ser da aprendizagem. Em um contexto de censuras, a tolerância surge como uma virtude revolucionária que consiste na convivência com o diferente. Para Chauí (2018), a ideologia hegemônica da classe dominante age por meio do imaginário coletivo, produzindo como consequência a falência do educador crítico. No contexto do movimento Escola Sem Partido, essa crise surge do equívoco pedagógico do docente neutro e "competente", fortalecido pela narrativa da corrupção generalizada da classe política. Como afirma Marielle Franco (2018, p. 93, grifo do autor): ${ }^{2}$

Esse quadrante [de opressões] se amplia, com o êxito das classes dominantes, nesse cenário de golpe, ao alargar a visão hegemônica de que o principal problema do Brasil é a corrupção e não as desigualdades. Ao mesmo tempo que tal visão ganha força no imaginário, cresce também uma rejeição à participação política e uma identificação de que os principais corruptos são os 'políticos'.

1 Expressão originária do verbo Poiéō (fabricar, executar, confeccionar), poiésis traduz-se por fabricação, confecção, preparação, produção. No entanto, um produzir que dá forma, instaura uma realidade nova, um ser. Para Jovelina de Souza (2007), no artigo "As origens da noção de poiésis", inexiste em Homero a poiésis para designar a produção de poesia, o que só aparece em Heródoto e mais frequentemente em Platão e Aristóteles. Entretanto, o sentido de poiésis como criação não é um fazer a partir do nada, como na tradição hebraica, mas no sentido grego de gerar e produzir por via da potencialidade preexistente que ganha forma. Nesse sentido, a poiésis material conduzirá à obra artesanal, enquanto a poiésis de natureza intelectual surge como criação poética. Ambas como realização do ato essencialmente livre que se destina para os gregos na formação dos cidadãos.

2 Marielle Franco foi a segunda mulher (mãe, negra e nascida na favela da Maré) a ocupar assento na Câmara Municipal do Rio de Janeiro - a quinta mais votada no Rio de Janeiro nas eleições de 2016, com 46.502 votos, pelo Partido Socialismo e Liberdade (PSOL). Se destacou como militante ativista das lutas feministas e antirracista, na defesa dos Direitos Humanos e da visibilidade lésbica, desde jovem. Passou a atuar como ativista após ingressar em um prévestibular comunitário. Formou-se em Sociologia pela PUC-RIO, com mestrado em Administração Pública pela Universidade Federal Fluminense (UFF). Sua dissertação de mestrado teve como tema: "UPP: a redução da favela a três letras." De modo bárbaro, foi assassinada no bairro do Estácio em 14 de março de 2018, na região central do Rio de Janeiro, quando voltava de um evento na Lapa. 
A postura de neutralidade axiológica manifesta um posicionamento ideológico dominante através da invisibilidade das identidades que se encontram em jogo nas situações limites da vida, produzindo-se a separação entre política e ética a partir da negação das alteridades de gênero, raça e classe. Com isso, vê-se uma fragilidade da democracia, na medida em que se cria um novo modelo de educação baseado na privatização e despolitização da vida social, através da ideologia dominante. Para Marilena Chauí (2018), se produz o discurso que a educação serve aos propósitos de "maximização do ganho" e aumento do consumo na esfera social, em substituição à participação política democrática, censurando o debate das opressões, das minorias sociais como LGBTs, negros e mulheres.

Tais atitudes geram o enfraquecimento do diálogo, em um contexto de crescimento do conservadorismo, sob a alegação de que todos os políticos são corruptos, segundo Franco (2018). Isso faz crescer o sentimento de ódio na política, e com isso vê-se a fragilidade das nossas relações, marcadas pelo autoritarismo do poder burocrático, através do golpe jurídico parlamentar contra Dilma Rousseff em 2016, seguido da vitória eleitoral à presidência em 2018 do candidato da extrema-direita Jair Messias Bolsonaro (PSL), em circunstâncias de intensos ataques à vida democrática, expressas pelo próprio movimento Escola Sem Partido.

Por isso, a compreensão do mundo, a concepção pedagógica e de vida, segundo Freire (2017b), é sempre um posicionamento político que encontra sua fonte de reflexão na ética por via da intencionalidade crítica e libertadora. Nesse sentido, salienta o filósofo andarilho da educação: "Aprender e ensinar fazem parte da existência humana, histórica e social como dela fazem parte a criação, a invenção, a linguagem, o amor, o ódio, o espanto, o medo e o desejo, a atração pelo risco[...]" (FREIRE, 2017b, p. 24).

Aprender e ensinar fazem parte da nossa condição ontológica, é nessa procura que se altera o modo como interpretamos, como re- fazemos a leitura do mundo através da prática. Desse modo, abre-se a possibilidade de se descobrir novos horizontes no mundo, percebendo que há outro modo de se ensinar o aprendido e aprender o ensinado, sem as hierarquizações preestabelecidas da educação domesticadora do conhecimento, numa reflexão ética do que se faz em torno das opções escolhidas.

As chamadas minorias, por exemplo, precisam reconhecer que, no fundo, elas são a maioria. 0 caminho para assumirem-se como maioria está em trabalhar as semelhanças entre si, e não só as diferenças, e, assim, criar, a unidade na diversidade, fora da qual não vejo como aperfeiçoar-se e até como construir-se uma democracia substantiva, radical. (FREIRE, 2018, p. 212).

Freire (2018) destaca-se como pensador das sínteses culturais, promovendo o conceito de educação popular em perspectiva intercultural, através do reconhecimento da unidade na diversidade. Aqui, faz-se indispensável a compreensão ética das interseccionalidades de gênero, raça e classe, que se estendem também às nações e fronteiras. Neste contexto, o pensamento crítico da libertação se caracteriza não por propor a simetria entre as culturas, tampouco o poder da cultura erudita sobre a cultura oprimida, mas como um movimento ético contrário à subalternização de uma cultural sobre a outra.

A tarefa filosófica e democrática da ética da alteridade surge com o risco de pensar as tensões próprias da relação entre as diferenças, sem medo da liberdade, agindo frente aos desafios que impõem a tarefa de ser mais, não se furtando através da prepotência própria daqueles que pretendem impor através do autoritarismo suas verdades, gerando ideologias, segundo Freire (2017a), discriminatórias, contra as quais se insurgem as ideologias de resistências.

Não é a cultura discriminada a responsável pela ideologia discriminatória. Neste caso, a visão acrítica da sociedade torna as minorias sociais responsáveis pela "crise de valores" da cultura hegemônica. Vejamos o que diz o 
Estatuto da Família apresentado na Câmara dos Deputados: "Art.2 Para os fins desta lei, define-se entidade familiar como o núcleo social formado a partir da união entre um homem e uma mulher, por meio do casamento ou união estável, ou ainda por comunidade formada por qualquer dos pais e seus descendentes." (BRASIL, 2013, p. 1).

0 projeto de Lei $\mathrm{n}^{\circ} 6.583$, de 2013 (BRASIL, 2013), que dispõe sobre o Estatuto da Família, de cuja comissão o Deputado Flávio Augusto da Silva (PSC/SP) é membro, traz uma concepção ideológica dos valores tradicionais, que se reflete diretamente na narrativa da ideologia de gênero utilizada pelos adeptos do movimento $\mathrm{ESP}^{3}$ Ao contrário da afirmativa de que a concepção de família é apenas heterossexual, binária, constituída pelo sexo biológico do homem e da mulher, existe no Brasil um debate democrático mais amplo que passa pela aprovação do casamento de pessoas do mesmo sexo. A partir da Resolução no 175, foi garantido aos casais homoafetivos o direito civil de casamento (GARONCE, 2017). Nesse contexto de crescimento dos ataques conservadores, o pensamento de Paulo Freire surge como um desafio reflexivo sobre a nossa presença no mundo, compreendendo que o fazer ético não se aplica a favorecimentos pessoais, mas surge como reconhecimento do Outro, fazendo a liberdade despertar de um projeto democrático e promovendo a unidade na diversidade através da ética da alteridade.

Caso a educação realmente encontrasse, como "obstáculo epistemológico", a falta de imparcialidade dos educadores (as), as práticas de aprendizagem se restringiriam à dita "competência" do professor bancário transmissor de conhecimentos, cuja dimensão ética se reduziria a um puro processo técnico e mecânico avalizado pelo próprio movimento ESP. Com uma diferente concepção, a educação é, na sua essência, o caminho do Eu face ao Outro; tal como se explicita no pensamento de Buber

3 A sigla ESP é uma referência ao Movimento Escola Sem Partido.
(2001), na palavra princípio EU-TU. À luz disso, vê-se melhor a impossibilidade de uma educação ética por via do projeto ESP.

Para o Deputado Federal Izalci Lucas Ferreira (PSDB/DF), os valores da família tradicional se encontram ameaçados pela "ideologia de gênero". Na redação do PL n 1.859/2015 (BRASIL, 2015), são citados supostos trechos das obras A Origem da Família, da Propriedade Privada e do Estado e A Ideologia Alemã. Segundo Derisso (2016), essas passagens fazem alusão à concepção de Marx e Engels sobre a família; entretanto, são montagens que não constam em nenhuma das obras dos filósofos.

Vejam a exposição da Ideologia Alemã neste documento:

Marx escreveu na sua obra 'A Ideologia alemã': 'A propriedade privada somente poderá ser suprimida quando a divisão do trabalho puder ser suprimida. A divisão do trabalho, porém, na sua origem, não é nada mais do que a divisão do trabalho no ato sexual, que mais tarde se torna a divisão do trabalho que se desenvolve por si mesma. A divisão do trabalho, por conseguinte, repousa na divisão natural do trabalho na família e na divisão da sociedade em diversas famílias que se opõem entre si, e que envolve, ao mesmo tempo, a divisão desigual tanto do trabalho como de seus produtores, isto é, da propriedade privada, que já possui seu germe na sua forma original, que é a família, em que a mulher e os filhos são escravos do marido.' (BRASIL, 2015, p. 4).

A interpretação realizada pelos defensores da Associação ESP encontra na referenciada obra de Marx e Engels alusão à abolição da família como um requisito político para supressão da divisão social do trabalho. Todavia, constata-se que tal indicação se trata de uma montagem, já que a mesma citação não faz referência a número de página, nem edição. Dessa maneira, o Requerimento de Informação do Deputado Izalci produz ataques contra o marxismo sem o devido compromisso intelectual. Assim, a afirmação do nosso atual patrono da educação brasileira volta a fazer novamente sentido: "O direito de criticar e o dever, ao criticar, de não faltar à verdade para apoiar 
nossa crítica é um imperativo ético de mais alta importância no processo de aprendizado de nossa democracia." (FREIRE, 2017b, p. 69).

Assumir a crítica é também reconhecer a possibilidade do erro. Nesse caso, o conhecimento crítico não se cristaliza face aos preconceitos. Pelo contrário, identifica que pensar e compreender o mundo não pode ser um ato delineado por uma única concepção política. Assim, não é possível, para Freire (2017a), exercer a liberdade de crítica com relação às injustiças sociais sem uma responsabilidade para com as pessoas implicadas. A crítica filosófica, quando aplicada com empenho ético, permite a ampliação dos horizontes através do olhar hermenêutico, transformando a percepção sobre as diferenças e tornando possível a construção política civilizatória como expressão fecunda do compromisso de não mentir em relação ao criticado.

É preciso, aos educadores(as) e educandos(as), a reflexão acerca do próprio inacabamento existencial que envolve as tensões do fazer educativo. Se admito que o pensamento único e dogmático é irrepreensível, não posso realizar a escuta sensível do diferente. Desta maneira, afirma Freire (1996), o respeito à diferença exige de mim humildade, que não significa verbalismo burocrático, nem formalismo, mas a certeza de que não somos superiores a ninguém; no entanto, também não somos inferiores. "O que a humildade não pode exigir de mim é a minha submissão à arrogância e ao destempero de quem me desrespeita." (FREIRE, 1996, p. 121).

Para Paulo Freire (1996), a humildade é uma exigência em favor da dignidade; como atitude ética, faz parte do respeito mútuo entre educadores(as) e educandos(as). Portanto, não representa demérito, mera "modéstia", fraqueza nem submissão ao poder dominante. Trata-se de uma atitude de humanização, visando o coletivo como compromisso solidário de conscientização.

Em um momento de ataques à autonomia docente, e crescimento do conservadorismo através de medidas inconstitucionais e arbitrárias próprias da época, já caracterizada por Freire (2001), de fechamento das experiências democráticas, surge o fenômeno do neofascismo, se manifestando com efeitos de "mobilização das massas", e produzindo como consequência política o impeachment da presidenta Dilma Rousseff em 2016, sob a ação seletiva do poder judiciário. Segundo Luciano Santos (2018), na publicação acadêmica Contra o golpe: caderno de democracia, produziu-se um golpe de Estado anticivilizatório, de alcance ético-narrativo, que reduziu o fazer político e democrático ao cumprimento da ordem social, de cunho legal, moralista e privatista, apoiada na gestão midiática dos interesses dominantes.

Tais medidas, que visam moralizar a ordem e combater a "corrupção de esquerda", através da ação jurídica própria do Estado de exceção, geraram como resultado político a ofensiva moralista no ambiente escolar, com a tramitação do Projeto de Lei no 7.800/2016 (ALAGOAS, 2016), aprovado no estado de Alagoas, tornando legal a lei da "Escola Livre". Entretanto, a aprovação do projeto Escola Sem Partido teve sua validade constitucional questionada pelo Supremo Tribunal Federal, através do Ministro Luís Roberto Barroso, que concedeu uma liminar suspendendo os efeitos da Lei até o julgamento final.

Vejamos o que diz a medida cautelar do STF:

A ideia de neutralidade política e ideológica da lei estadual é antagônica à de proteção ao pluralismo de ideias e de concepções pedagógicas e à promoção da tolerância tal como prevista na Lei de Diretrizes e Bases. A imposição da neutralidade - se fosse verdadeiramente possível -impediria a afirmação de diferentes ideias e concepções políticas ou ideológicas sobre um mesmo fenômeno em sala de aula. A exigência de neutralidade política e ideológica implica, ademais, a não tolerância de diferentes visões de mundo, ideologias e perspectivas políticas em sala de aula. (BRASIL, 2017, p. 12).

A neutralidade política e ideológica, segundo o parecer do Ministro Luís Barroso, é antagô- 
nica à própria Lei de Diretrizes e Bases, que expressa de forma clara a pluralidade e diversidade como fundamento ético indispensável ao fazer democrático. Não obstante, a narrativa de neutralidade axiológica implica a intolerância que, para Freire (2017a), é acrítica, dogmática e castradora. Neste caso, os diferentes projetos do Escola Sem Partido, apensados ao relatório do Deputado Flavinho e arquivados pela Câmara em dezembro de 2018, são, no fundo, uma concepção ideológica de escola, submetida às limitações sociais que a tornam um lugar de transmissão de conhecimentos previamente selecionados, e imunizada aos conflitos ideológicos, às lutas sociais e à militância de esquerda.

Nessas circunstâncias, cresce o sinal de autoritarismo a partir das proposições do movimento Escola Sem Partido, que, através do "pensamento único", torna-se indiferente à capacidade crítica dos educadores, traduzindo-se na descrença em relação ao potencial insurgente dos educandos, e na tentativa de esvaziamento do poder de contestação das minorias no espaço escolar. 0 movimento ESP procura impedir a identificação dos estudantes com movimentos de mulheres, LGBTs ou de resistência étnico-racial, com lutas sindicais ou estudantis.

Como contraponto a essas medidas de supervisão do trabalho docente no espaço escolar, Paulo Freire, em 1989, foi responsável pela criação da escola cidadã, uma iniciativa do filósofo da educação quando se tornou secretário de Educação do Estado de São Paulo, no governo de Maria Luiza Erudina. Freire propôs um programa de democratização da gestão escolar, fortalecendo a concepção da educação popular através de propostas de inclusão voltadas, principalmente, para jovens e adultos das periferias. Com tais iniciativas, a escola pública se fortaleceu como espaço de construção da educação popular, fomentando a compreensão crítica das tensões como manifestação humana própria do fazer político democrático.

\section{Os fundamentos gnosiológicos}

\section{da educação crítica no contexto da Escola Sem Partido}

Uma crítica aos fundamentos gnosiológicos da educação passa pelo conceito de extensão, ${ }^{4}$ usado por Freire (2011), que reflete uma concepção bancária do fazer educativo, cujas práticas encontram-se expressas nas narrativas do movimento Escola Sem Partido. 0 educador extensionista acredita na transmissão do conhecimento a partir da seleção prévia de conteúdos e rotas pré-estabelecidas pelo sistema bancário de educação. Desse modo, o movimento ESP deixa clara a sua concepção de aprendizagem, o que produz no atual contexto um equívoco gnosiológico da "extensão educativa", resultando em uma prática domesticadora e na falsa concepção de que é função do professor transferir conteúdos programáticos; por isso, é preciso "saber que ensinar não é memorizar ou arquivar conhecimentos, mas criar as possibilidades para a sua própria produção ou a sua construção" (FREIRE, 1996, p. 47).

0 extensionismo é um conceito que reduz o conhecimento do educador a si mesmo, sem a interpelação ética da alteridade entre educadores e educandos; os conteúdos são compreendidos como estáticos e mecânicos. Por isso, as proposições da educação bancária pertencem a um conjunto de opiniões (doxa) acerca do ato de ensinar, as quais terminam por se antecipar frente às coisas mesmas. 0 mundo humano, para o filósofo da educação, é comunicação, construído pela interação intersubjetiva; assim, Freire (2011), estudando

40 conceito de extensão aparece no ensaio Extensão ou comunicação? (FREIRE, 2011), escrito por Paulo Freire em 1968, em Santiago do Chile, para o Instituto de Capacitación e Investigación en Reforma Agrária. A apropriação semântica do termo extensão é uma crítica ao trabalho do agrônomo como estratégia política para a América Latina. Segundo Leopoldo Zea (2014), os conceitos de "dependência" e de invasão cultural de Freire dão a tônica da realidade latino-americana nos anos 1960 e 1970 . Por isso, o termo extensão confere uma conotação ao ato de transmissão do conhecimento, como invasão cultural e manipulação. 
as três relações constitutivas do conhecimento, gnosiológica, histórica e lógica, inseriu uma última e fundamental relação, sob influência de Eduardo Nicol - o diálogo como fonte crítica de libertação.

O ensino de filosofia, no contexto da ESP, encontra obstáculos ao desenvolvimento da reflexão crítica e comunicativa. Sem a novidade do risco, sem os fundamentos de uma racionalidade concreta desvelada pela práxis social, as razões ontológicas, epistemológicas e políticas da teoria tornam-se abstratas e sem sentido. Quando, a partir da aspiração de Freire como filósofo da esperança, se consideram as reais condições pedagógicas do ensino da filosofia, pode-se dimensionar a gravidade dos ataques que o pensamento fecundo vem sofrendo por parte dos setores conservadores.

Por isso, a liberdade de crítica e o direito de ensinar não se identificam, em nosso atual contexto, com as proposições de neutralidade axiológica do movimento Escola Sem Partido, que formula suas concepções e práticas como extensão autoritária, sem perceber que educadores e educandos já se encontram envolvidos na prática educativa. Assim, para Freire (1996, p. 49), "Pensar certo - é uma postura exigente, difícil, às vezes penosa, que temos de assumir diante dos outros e com os outros".

Não significa, com isso, que pensar certo seja uma atividade puramente angelical, que pertença apenas aos sábios, mas, por ser o pensamento um parto doloroso, devemos exercer vigilância sobre o simplismo e incoerências grosseiras. Pensar certo exige a humildade como sentido filosófico, se desfazendo da concepção judicativa e persecutória e, muitas vezes, raivosa, daqueles que terminam por propagar o ódio na política com formulações preestabelecidas e que fazem da educação um ambiente de censura à diversidade cultural. A educação brasileira, no cenário do movimento ESP, produz um decalque da tradição bancária, uma educação sem o risco de aprender, mesmo que rasurando. No entanto, sem o anúncio da utopia, não se reinventa o sentido de investi- gação, não se cria a possibilidade da aprendizagem como síntese dialética.

Por isso, as narrativas do movimento ESP representam o medo da liberdade por meio da antecipação adjudicativa da compreensão do mundo frente às coisas mesmas, o que termina por definir o trabalho docente como prática de transmissão de conteúdos neutros, em que os educandos sempre se encontram em uma situação estática, própria de um contexto social de horizontes fechados. Assim, forma-se o aprendente memorizador, através da educação bancária, a partir da primazia de alguém que está sempre certo de suas certezas. A prática educativa crítica libertadora, para Freire (2011), é construída por uma "dodiscência, docência-discência", formando ciclos gnosiológicos.

Daí que seja tão fundamental conhecer o conhecimento existente quanto saber que estamos abertos e aptos à produção do conhecimento ainda não existente. Ensinar, aprender e pesquisar lidam com esses dois momentos do ciclo gnosiológico: o que se ensina e se aprende, o conhecimento já existente e o que se trabalha, a produção do conhecimento ainda não existente. (FREIRE, p. 1996, p. 28).

Nesse sentido, é fundamental ao educador crítico estar existencialmente aberto às possibilidades do aprender, na medida em que, enfrentando o medo da liberdade, se reconhece que o ato educativo não é cópia das formulações preestabelecidas; entretanto, é tarefa de uma educação crítica e reflexiva manter o sujeito pedagógico encarnado na práxis da temática investigativa, o que significa um trabalho rigoroso em busca do conhecimento crítico.

Por isso, o movimento ESP, ao atribuir exclusividade à família e à religião como únicos responsáveis pela educação moral de seus filhos, pressupõe, segundo os termos de Freire (2011), uma idealização conformista, cuja compreensão adjudicativa dos valores da família tradicional produz censuras no ambiente de aprendizagem, construindo uma etapa de retrocesso nas experiências democráticas. A 
partir do fechamento do horizonte do educando em uma educação prescritiva, constatam-se mais obstáculos de cunho epistemológico na construção da consciência crítica. Assim reza a cartilha seguida pelo ESP:

Definitivamente o homem não pode produzir conhecimento sem que seja fruto de interação do sujeito cognoscente com o objeto cognoscível. Mas isso não nos autoriza a depreciar toda e qualquer forma de imparcialidade ou de rejeitar qualquer busca pela objetividade, mesmo que incompleta e relativa, pois isso nos levaria a uma epistemologia extremamente subjetivista que minaria as próprias bases da ciência contemporânea. Portanto, é claro que é possível agir com o máximo de neutralidade em muitos contextos. E naqueles contextos mais controversos, em que a imparcialidade é realmente difícil, espera-se de um profissional ético e qualificado que, no mínimo, forneça aos alunos uma perspectiva plural. (BRASIL, 2018, p. 9).

Disso decorre a problematização do ato educativo como desafio para o pensamento crítico libertador em nosso atual cenário. 0 relatório (BRASIL, 2018) do Deputado Flavio Augusto da Silva (PSC) reduz o ambiente de aprendizagem a uma epistemologia da quase imparcialidade, o que vem a significar a recusa dos saberes e experiências sociais produzidos pelo esforço, segundo Torres (2014), dialético de compreensão na relação entre subjetividade e objetividade, tornando o movimento ESP uma tentativa de anulação arbitrária dos direitos sociais construídos a partir das lutas democráticas por ampliação das liberdades civis e da participação popular.

0 ensino de filosofia, em tal contexto, encontra o desafio de pensar a dificuldade de reconhecimento das diferenças. Com efeito, vem se esvaziando a importância temática da discussão da Diversidade Cultural, que identifica como atitude libertadora a luta de mulheres, LGBTs e populações afrodescendentes contra as discriminações, bem como a luta pela reconquista de territórios das populações originárias, quilombolas ou ciganos, que veem cotidianamente seus saberes e pertencimentos culturais se tornando invisíveis, sofrendo ataques por parte dos setores fundamentalistas a partir de uma pauta política conservadora de retomada do "moralismo" e dos direitos da família tradicional, sob a narrativa da neutralidade científico-pedagógica expressa pelo próprio movimento, que pretende amordaçar professores.

Desse modo, é pertinente a educadoras e educadores comprometidos com o bem pensar problematizar o contexto social dos educandos, e as palavras geradoras construídas na interação gnosiológica. 0 que Freire (2011) projeta na relação intersubjetiva do ato educativo vale como antídoto à neutralidade axiológica. Com isso, a prática educativa apenas é possível como pensamento fecundo quando encarnada na atitude ética face às mais diversas alteridades humanas, com seus respectivos saberes.

Assim, pensar certo exige respeito ao conhecimento dos educandos, mas também estímulo à sua capacidade criadora. 0 principal desafio dos(as) professores(as) diante da prática educativa filosófica é o de estimular as curiosidades epistemológicas, abrindo novos horizontes na relação de educadores e educandos, projetando dúvidas acerca dos saberes dados, contra a postura intransitiva e dogmática do educador bancário que termina por produzir uma concepção pedagógica fatalista, transformando o educando em um corpo domesticado, negando a condição de sujeito ativo na construção do conhecimento, reduzindo, enfim, o ensino de filosofia a prescrições normativas e superficiais.

O equívoco gnosiológico do extensionismo consiste, para Freire (2011), na falta de abertura à interpelação do Outro, e no fechamento do conhecimento em si mesmo. 0 que reproduz a concepção de aprendizagem estática, acrítica e de conhecimento ingênuo.

A reflexão filosófica se impõe neste como em outros casos. Não é possível aludi-la, já que o que a Extensão pretende, basicamente, é substituir uma forma de conhecimento por outra. E basta 
que esteja em jogo formas de conhecimento para que não se possa deixar de lado uma reflexão filosófica. 0 fundamental, porém, é que esta reflexão, de caráter teórico, não se degenere nos verbalismos vazios nem, por outro lado, na mera explicação da realidade que devesse permanecer intocada. (FREIRE, 2011, p. 27).

0 ensino de filosofia requer a construção de uma etapa de mediação cognitiva entre sujeitos cognoscentes e objetos cognoscíveis. Neste sentido, a postura pedagógica do educador extensionista reproduz a visão da docência como sujeito detentor e transmissor de conhecimentos técnicos. Desse modo, insiste Freire (2011), uma educação crítica e filosófica é capaz de reinventar existencialmente a situação aprendida. Com isso, no nível filosófico a intencionalidade do educando se transforma quando este deixa a dimensão operante do senso comum e torna-se indagador das circunstâncias concretas do mundo da vida.

Em um contexto de crescimento das apelações políticas neofascistas, as proposições arbitrárias em torno do educador "competente" reproduzem, através dos crescentes discursos "moralistas", mais uma crise da atividade docente. Sob a narrativa de imparcialidade epistemológica, a educação retorna ao paradigma do educador extensionista e transmissor de saberes neutros, o que torna o movimento Escola Sem Partido um equívoco gnosiológico da prática educativa.

\section{0 currículo de filosofia diante da Escola Sem Partido}

Os componentes curriculares, na concepção da pedagogia popular de Freire, são o resultado das demandas suscitadas pelo próprio círculo de cultura em que os discentes se encontram inseridos. 0 ensino de filosofia, no contexto da educação básica atual, vem enfrentando diversos problemas em relação à prioridade de conteúdos programáticos. Tais problemas surgem como uma consequência das influências políticas e epistemológicas que constituem obstáculos à prática pedagógica na educação brasileira.

Com base na compreensão radical e fecunda do pensamento de Freire (2011), há uma impossibilidade dos projetos apensados ao Relatório do Escola Sem Partido (BRASIL, 2018) - apresentado na sala de comissão do Congresso em 08 de maio de 2018 - expressarem alguma coerência com a complexidade curricular do ato de ensinar. 0 professor de filosofia não representa, para Freire (1996), um mero transmissor de conhecimentos pré-estabelecidos; suas abordagens temáticas deveriam encontrar-se - na contramão da concepção bancária da educação - sempre em articulação com as circunstâncias da vida política.

Por isso, a educação, para Freire (1996), é reinvenção do modo de investigar e de questionar o saber proprietário. 0 bem pensar exige a dúvida das certezas, na medida em que assume a aventura do saber como possibilidade. Por isso, aprender e ensinar é estar existencialmente aberto ao horizonte cognoscível e temático do educando. Tendo como base a fé no diálogo, passa-se à fase da problematização do universo temático das percepções destacadas, criandose o encontro dos horizontes.

Desse modo, impõe-se como desafio filosófico a construção de um currículo crítico, capaz de alcançar o logos do saber educativo: "Cabe à reflexão incidir sobre a ação e desvelá -la em seus objetos, em seus meios, em sua eficiência." (FREIRE, 2011, p. 47). Ora, uma educação domesticadora autorreferenciada no educador extensionista é um equívoco gnosiológico que impede a construção de um currículo crítico, criando a ilusão do educador como único detentor do saber. 0 pensamento ingênuo é facilmente manipulável, tornando a ação diretiva da educação em narrativas autoritárias, mantendo-se os conflitos escolares pela subalternização hierárquica do saber.

Na obra $A$ condição pós-moderna, Lyotard (2011, p. 13) afirma: "A questão da legitimidade encontra-se, desde Platão, indissoluvelmente associada à legitimação do legislador." Tal 
mensagem é cada vez mais atual, na medida em que o poder público insere o conhecimento prescritivo e de fácil decodificação no contexto de mercantilização do saber, a fim de otimizar a compreensão tecnicista, aumentando a performance dos saberes considerados legítimos.

Freire (2017a), como filósofo andarilho da esperança, afirma, na Pedagogia do Oprimido, que a dialogicidade do processo educativo não começa, enquanto situação pedagógica, no encontro de educadores(as) e educandos(as), mas, antes mesmo, inicia-se no questionamento docente acerca dos conteúdos do diálogo, surgindo como inquietação em face dos obstáculos epistemológicos para a compreensão dos conteúdos programáticos. Por isso, uma educação problematizadora não é a imposição de conhecimentos a serem depositados nos educandos. A educação crítica tem como desafio gnosiológico devolver, de modo organizado, aos educandos as questões sensíveis geradas nos círculos de cultura, através da interação pedagógica e da partilha ativa na construção do conhecimento gerado pela coletividade.

A experiência do círculo de cultura produz, no ambiente de aprendizagem, segundo o Dicionário Paulo Freire (STRECK; REDIN; ZITKOSKI, 2008), um desejo de democratização da palavra, do poder compartilhado como participação consciente. Nesse contexto, o movimento Escola Sem Partido defende uma intervenção arbitrária através do poder público de caráter político, que promova interferências diretas nas relações entre teoria e prática do fazer educativo, produzindo consequências sobre o currículo crítico. Por isso, o ensino de filosofia é uma reinvenção do direito de pensar como práxis, através do compromisso com a educação libertadora. Assim, surge a etapa de conscientização a partir das percepções destacadas, em que os oprimidos vão realizando através do diálogo novas leituras do mundo, refletindo sobre as antigas representações dos valores e das regras sociais e políticas, frente à profecia do novo que surge de um sonho de liberdade.
Nesse sentido, a libertação do opressor hospedado na consciência dos oprimidos é um desafio humanista que exige, para Freire (2017a), certa prudência, por não se tratar de uma oposição precipitada aos slogans dominantes. Não obstante, é apenas através do diálogo com os educandos que as intuições operantes, comuns ao estágio da consciência ingênua no qual se encontra a maioria dos oprimidos, vão paulatinamente dando lugar a novas percepções de si e do mundo, que passam a refletir o caráter dúbio da consciência. No contexto do movimento Escola Sem Partido, o exame acerca desses valores surge como constatação da ideologia dominante gerada pelos valores tradicionais do conquistador.

Entretanto, o que se pretende com o diálogo não é um jogo intelectualista de palavras vazias. 0 educando, quando submetido a uma educação tecnicista do memorizar, ler e contar, é compelido à condição, segundo Freire (2011), de "tabula rasa", se encontrando desprovido da experiência de sentido. Por isso, o aluno, sob essas condições políticas e pedagógicas, no melhor dos casos apenas "disserta" sobre a tradição, sem o devido cotejo hermenêutico das fontes, não entendendo, segundo Adriano Nogueira (FREIRE; NOGUEIRA, 1993), a expressão corporal prévia que constitui a manifestação da linguagem e dos valores culturais dos educandos, como fase imprescindível à problematização da prática.

O melhor aluno de filosofia não é o que disserta, ipsis verbis, sobre a filosofia da mudança em Heráclito, sobre o problema do Ser em Parmênides; sobre o 'mundo das ideias' em Platão; sobre a metafísica em Aristóteles, ou, mais modernamente, sobre a 'dúvida' cartesiana, 'a coisa em si' em Kant; sobre a Dialética do Senhor e do Escravo em Hegel; a alienação em Hegel e em Marx, a intencionalidade da consciência em Husserl. 0 melhor aluno de filosofia é o que pensa criticamente sobre todo este pensar e corre o risco de pensar também. (FREIRE, 2011, p. 68, grifo do autor).

No contexto de crescimento das narrativas de neutralidade do saber, o ensino de filosofia 
não pode prescindir da problematização na construção de suas investigações temáticas. Não é possível uma reflexão filosófica do educando, cuja intencionalidade esteja separada do mundo prático (Lebenswelt). Por isso, tampouco é possível uma prática de ensino de filosofia com o percurso teórico e conceitual previamente definido pelo educador sem a demonstração de nenhum interesse pelo conhecimento popular. Sem a interpelação do mundo do educando, sem o reconhecimento de sua linguagem, reproduz-se um ambiente de aprendizagem em que "Interessa-nos, pelo contrário, que 'conheçam' o que conhecemos e da forma como conhecemos. E quando assim nos comportamos, prática ou teoricamente, somos autoritários [...]." (FREIRE, 2017b, p. 67, grifo do autor).

Esse ambiente de fechamento das experiências democráticas é justamente o que se evidencia com a aprovação do Plano Nacional de Educação (PNE) em 2014. Enquanto a versão anterior da Lei no 10.172 (BRASIL, 2001) por inúmeras vezes se referiu à igualdade de gênero, o PNE de 2014 (BRASIL, 2014) apenas foi aprovado diante da retirada do termo "gênero" da redação do Projeto de Lei. Consuma-se, desse modo, um acordo no Congresso entre os Deputados/pastores Marco Feliciano (PSC/ SP, atual PODEMOS), Marcos Rogério (PDT/ RO) e Pastor Eurico (PSB/PE), que conseguiram a aprovação, em votação na Câmara dos Deputados, de um dos pontos mais polêmicos do projeto. Com isso, foi retirada do projeto a superação das desigualdades educacionais, "com ênfase na promoção da igualdade racial, regional, de gênero e de orientação sexual" (FERNANDES, 2014).

A versão final do projeto foi substituída por "superação das desigualdades educacionais com ênfase na cidadania e todas as formas de discriminação" (BRASIL, 2014). Por isso, o currículo crítico precede de antemão à reflexão filosófica, como tarefa indispensável à possibilidade do pensar. Neste caso, o movimento Escola Sem Partido é um obstáculo ao pleno desenvolvimento da democracia, produzindo efeitos autoritários à liberdade de ensinar, sob alegação de falta de responsabilidade dos educadores.

O problema fundamental, de natureza política e tocado por tintas ideológicas, é saber quem escolheu os conteúdos, a favor de quem e de que estará o seu ensino, contra quem, a favor de que, contra quê. Qual o papel que cabe aos educandos na organização programática dos conteúdos; qual o papel, em níveis diferentes, daqueles e daquelas que, nas bases, cozinheiras, zeladores, vigias, se acham envolvidos na prática educativa da escola, qual o papel das famílias, das organizações sociais, da comunidade local? (FREIRE, 2018, p. 152).

Na concepção de Freire (2018), é a partir da situação existencial concreta do povo que se organizam os componentes curriculares. Os conteúdos não podem ser uma doação acrítica e fora do contexto social do educando. O conteúdo é uma organização, segundo o Dicionário Paulo Freire (STRECK; REDIN; ZITKOSKI, 2008), de métodos e conhecimentos indissociáveis da relação entre pensamento e linguagem. Por isso, Freire (2017a) propõe, na Pedagogia do Oprimido, que o desafio do educador na organização dos conteúdos programáticos passa pelo critério de identificação das contradições sociais que se refletem nas condições existenciais, culturais e políticas, na formação da cidade e na vida dos cidadãos, constituindo como fonte de sentido as situações-problemas que estimulam a curiosidade e a formação do pensamento crítico.

Todavia, em um contexto de censura, o que se constata são formulações prescritivas dos proferidos deveres do professor, que criam maiores dificuldades à sociabilidade, à liberdade e à almejada democracia.

\footnotetext{
ANEXO - DEVERES DO PROFESSOR - I - 0 professor não se aproveitará da audiência cativa dos alunos, com o objetivo de cooptá-los para nenhuma corrente política, ideológica ou partidária; II - 0 professor não favorecerá nem prejudicará os alunos em razão de suas convicções políticas, ideológicas, morais ou religiosas; III - 0 professor não fará propaganda político-partidária em sala de aula nem incitará seus
} 
alunos a participar de manifestações, atos públicos e passeatas; IV - Ao tratar de questões políticas, socioculturais e econômicas, o professor apresentará aos alunos, de forma justa - isto é, com a mesma profundidade e seriedade -, as principais versões, teorias, opiniões e perspectivas concorrentes a respeito; V - 0 professor respeitará o direito dos pais a que seus filhos recebam a educação moral que esteja de acordo com suas próprias convicções; VI - O professor não permitirá que os direitos assegurados nos itens anteriores sejam violados pela ação de terceiros, dentro da sala de aula. (BRASIL, 2018, p. 27).

Essa proposta de cartaz a ser fixado nas salas de aula, segundo o próprio Relatório apresentado na Câmara dos Deputados, já produz a política de amordaçamento no primeiro artigo, quando afirma que "o professor não se aproveitará da audiência cativa dos alunos" (BRASIL, 2018, p. 27). De imediato, surge a concepção dos(as) alunos(as) arquivistas de Paulo Freire (2017a), sem o poder de criação, vistos como extensão dos conhecimentos considerados legítimos, e hierarquicamente submetidos à condição de "tábulas rasas", a serem preenchidas pelos valores dominantes.

Tal prerrogativa torna-se mais problemática quando, no item I, se adverte que os alunos não podem ser cooptados por uma tendência que se expresse de forma política ou partidária (BRASIL, 2018). Com isso, o tema gerador do currículo crítico é estabelecido por via de um artifício jurídico transformado em doutrinação. No Dicionário Paulo Freire (STRECK; REDIN; ZITKOSKI, 2008, p. 448), encontramos a seguinte afirmação: "Pessoas não se dissociam de filosofias, pensares, saberes, práticas e cotidiano. Em Paulo Freire jamais podem dissociar-se vida e luta política". No item II, segue a afirmação de que os professores se manterão de modo imparcial diante dos alunos, sendo vedada a exposição de suas concepções políticas, ideológicas, morais ou religiosas (BRASIL, 2018).

Tais declarações aparecem num ambiente educacional separado do cotidiano da vida, da ação, das tensões que formam as contradições sociais e políticas que se refletem diretamente no trabalho do educador. Desse modo, afirma Freire (1986) em Medo e ousadia, apenas os educadores democráticos alteram sua prática frente aos obstáculos epistemológicos que impõem medo aos sonhos de um mundo mais justo. A censura estabelecida aos educadores e educadoras, tal como pronunciada no item III (BRASIL, 2018), cria uma atmosfera de controle do ambiente de aprendizagem, estimulando os alunos a denunciarem os educadores que venham a incentivá-los a participarem de passeatas, manifestações ou atos públicos.

O movimento ESP resulta em um aprofundamento do descrédito do trabalho docente, retirando a autoridade dos educadores e educadoras e criando maiores obstáculos ao pensamento crítico. Tais empecilhos tornam ainda mais difícil a libertação crítica dos educandos; todavia, é impossível, segundo Freire (1996), que os discentes alcancem de fato maior autonomia sem a autoridade e liberdade dos educadores. No item IV, é advertido que, ao tratar-se das questões culturais, políticas e econômicas, serão apresentadas teorias e versões concorrentes a respeito dos temas em questão (BRASIL, 2018). Com isso, as secretarias de educação ficam responsáveis pela criação de um canal de comunicação com a função de receber, segundo Cunha (2011), as denúncias anônimas dos estudantes contra professores supostamente "partidários".

A aplicação dessas censuras também se estende aos livros didáticos e à avaliação do Programa Nacional do Livro Didático (PNLD). Com isso se endossa a liberdade de aprender do aluno, vedando a liberdade de ensinar do professor, o que significa, para o ensino da filosofia, o ultimato final à possibilidade de uma educação libertadora.

[...] o currículo da Educação Básica, particularmente das escolas públicas, é objeto de ação modeladora que visa frear os processos de secularização da cultura e de laicidade do Estado, mediante dois movimentos, um de contenção, outro de imposição. Ambos os movimentos configuram um projeto de educação reacionária, entendida aqui como a que se opõe às mudanças sociais em curso e se esforça para restabelecer situações ultrapassadas. (CUNHA, 2016, p. 2). 
Para Luiz Antônio Cunha (2016), no artigo “O projeto reacionário na educação", existe em curso uma modelagem política por parte dos setores conservadores que produz efeitos semelhantes à invasão cultural identificada por Freire (2017a) na Pedagogia do Oprimido. Por isso, identifica Cunha (2016), os processos de laicização do Estado e secularização da cultura encontram obstáculos que se refletem diretamente no currículo da Educação Básica, produzindo efeitos de imposição. Segundo Fernanda Pereira de Moura (2018), no artigo “O movimento Escola Sem Partido e a reação conservadora contra a discussão de gênero na escola", a ação parlamentar age por meio de projetos e ações políticas governamentais que procuram inserir a obrigatoriedade do ensino religioso fundamentalista nas escolas e disciplinas como Moral e Cívica. Já os movimentos que produzem "contestações" são representados pelos ataques do programa Escola Sem Partido.

Nesse sentido, os professores não terão liberdade de expressão nem de manifestação crítica e se encontrarão, caso cumprido o desiderato do movimento ESP, no ambiente escolar como agentes das convicções dos pais conservadores. Essa atitude autoritária representa uma estratégia política maior, na medida em que se produz a imagem do "professor doutrinador" que comete abusos no direito de ensinar. Procura-se, com isso, impedir um debate aberto e crítico acerca de temáticas próprias da democratização, tornando a escola partidária dos valores tradicionais da família, estimulando um currículo escolar reprodutor de discriminações através das narrativas preconceituosas da "ideologia de gênero", da superioridade racial e de classes, em um contexto de crescimento do ódio na política.

\section{REFERÊNCIAS}

AGAMBEN, Giorgio. Estado de exceção. Trad. Iraci D. Poleti. São Paulo: Boitempo, 2004.

ALAGOAS. Assembleia Legislativa de Alagoas. Projeto de Lei $\mathrm{n}^{\circ} \mathbf{7 . 8 0 0}, 05$ de maio de 2016 .
Institui, no âmbito do Sistema Estadual de Ensino, o Programa "Escola Livre". Maceió, 2016. Disponível em: https://sapl.al.al.leg.br/norma/1195. Acesso em: 20 jan. 2019.

BRASIL. Presidência da República. Casa Civil. Lei no 10.172, de 09 de janeiro de 2001. Aprova o Plano Nacional de Educação e dá outras providências. Brasília, DF, 2001. Disponível em: http://www. planalto.gov.br/ccivil_03/Leis/LEIS_2001/L10172. htm. Acesso em: 14 nov. 2018.

BRASIL. Câmara dos Deputados. Projeto de Lei no 6.583, de 2013. Dispõe sobre o Estatuto da Família e dá outras providências. Brasília, DF, 2013. Disponível em: http://www.camara.gov.br/proposicoesWeb/ prop_mostrarintegra?codteor $=1159761$. Acesso em: 20 jan. 2019.

BRASIL. Presidência da República. Casa Civil. Lei no 13.005, de 25 de junho de 2014. Aprova o Plano Nacional de Educação - PNE e dá outras providências. Brasília, DF, 2014. Disponível em: http://www.planalto.gov.br/ccivil_03/_ato20112014/2014/lei/l13005.htm. Acesso em: 14 nov. 2018.

BRASIL. Câmara dos Deputados. Projeto de Lei no 1.859, de 09 de julho de 2015. Acrescenta Parágrafo único ao artigo 3o da Lei 9.394/96 (Lei de Diretrizes e Bases da Educação). Brasília, DF, 2015. Disponível em: https://www.camara.leg.br/ proposicoesWeb/prop_mostrarintegra;jsessionid= F9DC193914263A3CC3D30975C72591EB.propos icoesWeb1? codteor $=1359704 \&$ filename $=$ Avulso+PL+1859/2015. Acesso em: 20 jan. 2019.

BRASIL. Supremo Tribunal Federal. Medida Cautelar na Ação Direta de Inconstitucionalidade no 5.537/AL. Relator: Ministro Roberto Barroso. Brasília, DF, 21 de março de 2017. Direito Constitucional. Ação Direta de Inconstitucionalidade. Programa Escola Livre. Lei Estadual. Vícios Formais (de competência e de iniciativa) e afronta ao pluralismo de ideias. Cautelar Deferida. Disponível em: http://portal.stf.jus.br/processos/ downloadPeca.asp?id=311456113\&ext=.pdf. Acesso em: 20 jan. 2019.

BRASIL. Câmara dos Deputados. Relatório da Comissão Especial destinada a proferir parecer ao Projeto de Lei no $\mathbf{7 . 1 8 0}$, de 2014 . Brasília, DF, 2018. Disponível em: http://www. escolasempartido.org/images/relator.pdf. Acesso em: 12 nov. 2018.

BUBER, Martins. Eu e tu. Trad. Newton Aquiles Von 
Zuben. 10. ed. São Paulo: Centauro, 2001.

CHAUÍ, Marilena. Em defesa da educação pública, gratuita e democrática. 1. ed. Belo Horizonte: Autêntica, 2018. (Coleção Escritos de Marilena Chauí, no ${ }^{6}$ ).

CUNHA, L. A. 0 projeto reacionário na educação. 2016. Disponível em: http://www. luizantoniocunha.pro.br/uploads/independente/1 EduReacionaria.pdf. Acesso em: 20 jan. 2019.

DERISSO, J. L. Marxismo e história da família: resposta aos opositores da chamada "ideologia de gênero" na educação. In: SEMINÁRIO NACIONAL DO HISTERDRB, 10., 2016, Campinas, SP. Anais [...]. Campinas, SP: Unicamp, 2016. Disponível em: https://www.fe.unicamp.br/eventos / histedbr2016/anais/pdf/1029-2729-1-pb.pdf. Acesso em: 20 jan. 2019.

FERNANDES, Sarah. Lobby conservador retira igualdade de gênero do Plano Nacional de Educação. Rede Brasil Atual (RBA), São Paulo, 22 abr. 2014. Disponível em: https://www.redebrasilatual. com.br/educacao/2014/04/lobby-conservadorretira-igualdade-de-genero-do-plano-nacionalde-educacao-5214.html. Acesso em: 14 nov. 2018.

FRANCO, Marielle. A emergência da vida para superar o anestesiamento social frente à retirada de direitos: o momento pós-golpe pelo olhar de uma feminista, negra e favelada. In: BUENO, W. Et al. Tem saída: ensaios críticos sobre o Brasil. São Paulo: Zouk/\#CDMJ, 2018. p. 89-95.

FREIRE, Paulo. Educação como prática da liberdade. 25. ed. São Paulo: Paz e Terra, 2001.

FREIRE, Paulo. Extensão ou comunicação. 15. ed. São Paulo: Paz e Terra, 2011.

FREIRE, Paulo. Pedagogia da autonomia: saberes necessários à prática educativa. 33. ed. São Paulo: Paz e Terra, 1996.

FREIRE, Paulo. Pedagogia da esperança: um reencontro com a pedagogia do oprimido. 24. ed. São Paulo: Paz e Terra, 2018.

FREIRE, Paulo. Pedagogia da tolerância. 5. ed. São Paulo: Paz e Terra, 2016.

FREIRE, Paulo. Pedagogia do oprimido. 64. ed. São Paulo: Paz e Terra, 2017a.
FREIRE, Paulo. Política e educação. 3. ed. São Paulo: Paz e Terra, 2017b.

FREIRE, Paulo; NOGUEIRA, Adriano. Que fazer: teoria e prática da educação popular. 4. ed. Petrópolis, RJ: Vozes, 1993.

GARONCE, Luiza. Casamento gay no Brasil completa 4 anos de regulamentação; leia histórias. Portal G1, Rio de Janeiro, 14 maio 2017. Disponível em: https://g1.globo.com/distrito-federal/noticia/ casamento-gay-no-brasil-completa-4-anos-deregulamentacao-leia-historias.ghtml. Acesso em: 11 dez. 2018.

LYOTARD, Jean-François. A condição pós-moderna. Trad. Ricardo Corrêa Barbosa. 14. ed. Rio de Janeiro: José Olympio, 2011.

MOURA, Fernanda Pereira de. O movimento Escola Sem Partido e a reação conservadora contra a discussão de gênero na escola. In: PENNA, Fernando; QUEIROZ, Felipe; FRIGOTTO, Gaudêncio (org.). Educação democrática: antídoto ao Escola sem Partido. Rio de Janeiro: UERJ/LPP, 2018. p. 89-110.

SANTOS, Luciano. O golpe de estado no Brasil como fenômeno anticivilizatório: kit didático de resistência crítico-militante em conjuntura golpista. In: SANTOS, Luciano; CARNEIRO, Nadia Virginia B. (org.). Contra o golpe caderno de democracia. Salvador: Edufba/Eduneb, 2018. p. 137-161.

SOUZA, Joselina Maria Ramos de. As origens da noção de Poíesis. Hypnos - Revista do Centro de Estudo da Antiguidade, São Paulo, ano 13, n. 19, p. 85-96, 2007.

STRECK, D.; REDIN, E.; ZITKOSKI, J. J. (org.). Dicionário Paulo Freire. 4. ed. Belo Horizonte: Autêntica, 2008.

TORRES, Carlos Alberto. Diálogo e práxis educativa - uma leitura crítica de Paulo Freire. Tradução Mônica Mattar Oliva. São Paulo: Loyola, 2014.

ZEA, Leopoldo. La Filosofia americana como Filosofia sin más. 2014. Disponível em: https:// cursosluispatinoffyl.files.wordpress.com. Acesso em: 19 mar. 2018.

Recebido em: 01/12/2019 Aprovado em: 21/03/2020 